\title{
Environmental Assessment of Natural \& Anthropogenic Hazards and Impact on Seawater Desalination along Red Sea Coast of Saudi Arabia
}

\author{
Omar Siraj Aburizaiza ${ }^{1}$, Nayyer Alam Zaigham ${ }^{1 *}$, Zeeshan A. Nayyar ${ }^{2}$, \\ Gohar A. Mahar ${ }^{1}$, Azhar Siddiq ${ }^{1,2}$, Sabahat Noor ${ }^{1}$ \\ ${ }^{1}$ Unit for Ain Zubaida Rehabilitation \& Groundwater Research, King Abdulaziz University, Jeddah, KSA \\ ${ }^{2}$ University of Karachi, Karachi, Pakistan \\ Email: *nazaigham@gmail.com
}

Received January 30, 2013; revised March 3, 2013; accepted March 14, 2013

Copyright (c) 2013 Omar Siraj Aburizaiza et al. This is an open access article distributed under the Creative Commons Attribution License, which permits unrestricted use, distribution, and reproduction in any medium, provided the original work is properly cited.

\begin{abstract}
The major part of the eastern coastline of Red Sea belongs to Saudi Arabia, which provides great potential for desalination activities, but not entirely free of risk as in general it is not environment-friendly. In recent years, the rapid urbanization processes on west coast of Kingdom have resulted in substantial growth of commercial and industrial centers that added to more water demand. As a consequence, reliance on desalinated water has increased markedly over the last few decades. As a leading producer of desalinated water, Saudi Arabia used to process more than 3.29 million $\mathrm{m}^{3} / \mathrm{day}$ from its plants along the Red Sea coast. At the same time, any adequate backup plan lacks to meet regular water demand(s) in case of unforeseen emergencies. Present integrated research studies have identified some of the natural and anthropogenic hazards, which may pose major threats to quality of seawater as well as to the desalination facilities themselves. In view of these hazardous conditions, the overwhelming dependence on seawater desalination appears to be in jeopardy and may affect water management strategy and future socioeconomic development. It is therefore suggested the need of alternate options for cultivation of standby water resources and other management strategies parallel to the seawater desalination on similar priorities.
\end{abstract}

Keywords: Natural Hazards; Red Sea; Desalination; Water Management; Saudi Arabia

\section{Introduction}

In recent years, Saudi Arabia has become the leading producer of desalinated water from the Red Sea [1]. In the wake of the first operations, progress in the field of desalination remained gradual for a time, but has accelerated rapidly in recent years [2,3] and thus, desalination activities were unilaterally given priority. Desalinated Red Sea water is now the main source of domestic water supply in the western parts of Saudi Arabia. In addition to the coastal cities of Jeddah, Yanbu, Jizan, Al-Wajh and others several interior ones, such as Makkah, Madina, Taif, Albaha as well as their surrounding areas, are becoming increasingly dependent on desalinated water. This trend represents a drastic shift from the conventional groundwater supply sources.

Interestingly, the inventory data of the International

*Corresponding author.
Desalination Association (IDA) show that there has been an explosion in the demand for further major expansion of desalination facilities in the Red Sea region. This demand is caused by natural growth processes of modern development, by migration from rural to urban areas and by the increase in the number of pilgrims visiting the Holy Places. For example, the population of Saudi Arabia has increased from 22.68 million in 2004 to more than 27.14 million in 2010 during last five years [4,5]. Likewise, the number of pilgrims has risen from 90,662 in 1923 to more than 3 million in 2010 [6].

During the last decade, multiple research delineating temporal variations in the physical and chemical characteristic parameters of the Red Sea was carried out to study the impact of desalination on the seawater. Results of these studies identified significant adverse environmental degradation causing deterioration to the seawaters, the coastlines, and the prevailing aquatic marine ecosys- 
tems [7-12]. Preliminary results of the study have been presented as poster \# NH31A-1526 in the American Geophysical Union (AGU) Fall Meeting of December 2011 [13].

Present paper describes identified hazards, like, submarine configuration, tectonic \& seismotectonics setups, volcanism, seawater inflows \& outflows, high salinity and other pollution contributors and their impacts on the desalination facilities along the Saudi Red Sea coast.

\section{Methodology: Integrated Approach}

The adopted methodology comprises of three steps: 1) acquisition of pertinent archive literature and data from different sources in regard to different disciplines associated directly and/or indirectly with seawater desalination; 2) processing of collected data, developing of different interactive overlays, their interpretations and models; 3) integration of deduced inferences made during the research processes and the recommendation for future sustainable alternatives.

Several maps and tables were prepared based on the acquired data. For example, the bathymetry map of Red Sea was developed by using the satellite data acquired from General Bathymetry Charts of Oceans (GEBCO) from the website of the National Geophysical Data Centre (NGDC) of the National Oceanographic and Atmospheric Administration (NOAA). The collected data were then transformed into shp-files by using ArcGIS software to prepare customized bathymetry map for the present study.

The tectonic map of the region was prepared by compiling the two-minute image-tiles downloaded from the website of NGDC and subsequently transferring the identified tectonic features [14]. For the preparation of seismicity trend maps, the relevant earthquake data were filtered out from the earthquake catalog of National Earthquake Information (NEIC) of the United States Geological Survey (USGS) [15]. Similarly, other data and satellite images, related to active volcanic activities and the salt-tectonics, acquired through literature research and NASA archive library and other cited sources have been assimilated in the study.

\section{Status of Seawater Desalination along Red Sea}

In Saudi Arabia, urban water demand has been met increasingly by desalinated seawater. The country's desalination technology has extensively been developed over the past 40 years and involves substantial cost because of its intensive energy use [16]. In 2005, the total world installed capacity for seawater desalination was about 27.8 million $\mathrm{m}^{3} / \mathrm{d}[17,18]$, and subsequently, was increased to 59.9 million $\mathrm{m}^{3} / \mathrm{d}$ [3]. Likewise in Saudi
Arabia, an increase of the desalinated water production was also increased from 0.68 to 1.1 billion $\mathrm{m}^{3} /$ year between 1992 and 2006 [19]. The cumulative water production, by using the mixed MSF, MED, and RO seawater desalination technologies, was estimated at the rates of about 3.29 million $\mathrm{m}^{3}$ /day along the Red Sea for Saudi Arabia [20].

The seawater desalination activities along the Red Sea coast were found on a large scale (Figure 1), with major congestions observed on the mid-eastern coast in the Yanbu-Shoiba-Assir area and near the northern end of the Red Sea, particularly in Aqaba and the Suez gulfs.

\section{Natural Hazards and Impact on Seawater \& Desalination}

A multidisciplinary research study has been carried out to identify hazards and to analyze the hazardous factors that may irreversibly affect the sustainability of the desalinated water-supply and/or the desalination facilities, and to assess the direct and/or indirect impacts on the long-term dependency of the seawater desalination networks in parts of Red Sea coast.

The natural threats include the 1) submarine configuration and geomorphology of Red Sea, 2) geotectonic setups, 3) seismicity trends, 4) volcanic activities, 5) natural factors causing constant increase of seawater salinity, 6) interactive chocking of out-flow as well inflow to/

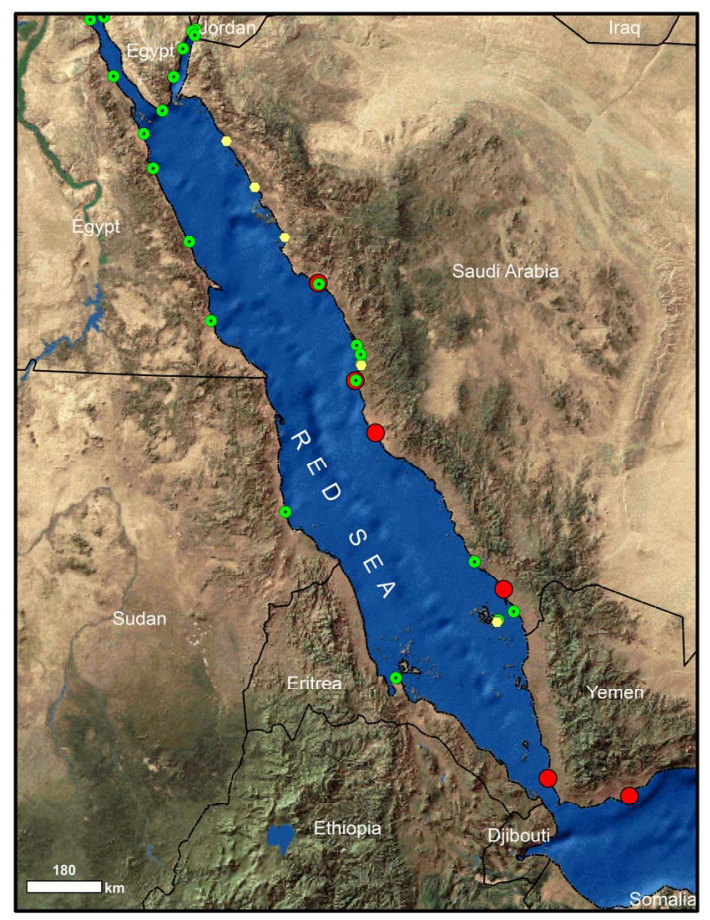

Figure 1. Locations of desalination plants along coastal areas of Red Sea. Red, pale and green balls represent MSF, MED and RO desalination plants respectively. Data source: [20]. 
from neighboring fresh and/or seawater sources.

\subsection{Submarine Configuration and Geomorphology of Red Sea}

Red Sea is an enclosed and elongated narrow salinewater body, sandwiched between African continent and Arabian Peninsula, except a bottleneck opening at Babel-Mandeb. Thus, it is practically isolated from the open ocean. It extends for a little more than 2000 kilometers from Suez-Aqaba Gulfs in north to Strait of Bab-el-Mandeb in south that further connects with the Aden Gulf and then Indian Ocean. The Red Sea is over 300 kilometers wide parallel to latitude $16^{\circ} \mathrm{N}$. However, the general width is about 250 kilometers that particularly shows acute tapering towards south-end. The bathymetry map shows distinct depth variation of Red Sea basin (Figure 2). Maximum depth, a little less than 3000 meters is in mid-part of central axial trough of the sea. However, average depth is about 500 meters.

The coastal shelf may be divided into two zones. Depth of the shallowest shelf ranges between 50 meters

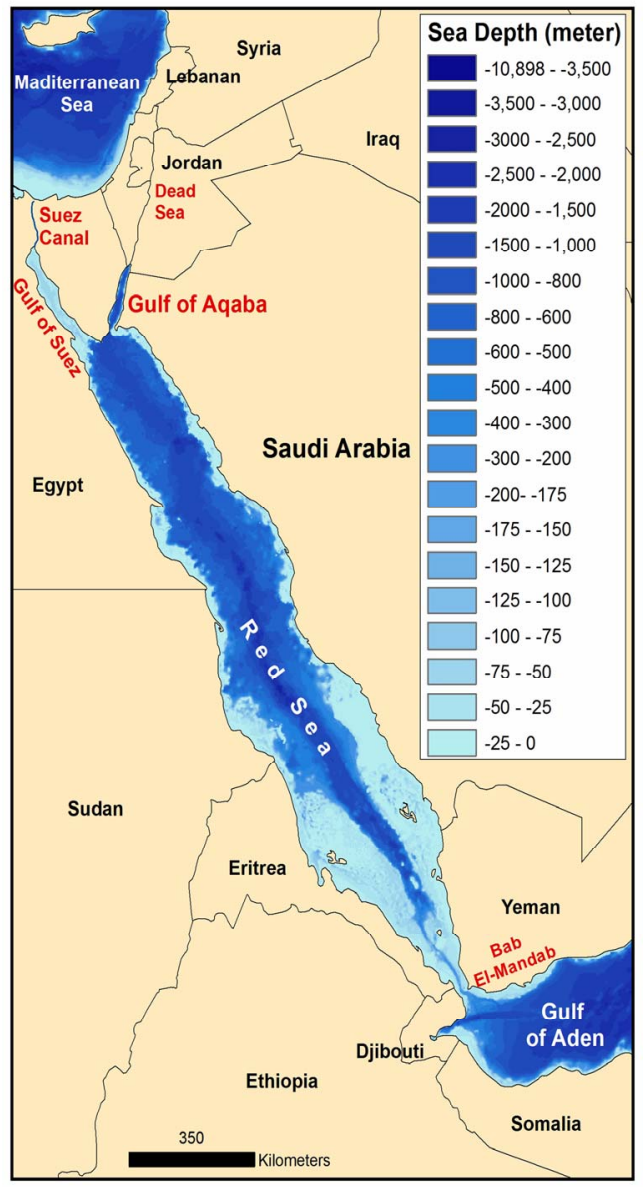

Figure 2. Customized bathymetry map of Red Sea in relation to Aden Gulf located in south, the Mediterranean Sea in the north and the enveloping countries of Red Sea. and 75 meters that is comparatively very narrow in northern half of the Sea with respect to southern half. The depth of deeper shelf may extend down to 500 - 600 meters. In the southern half, the shallow shelf dominantly widened extending up to Bab-el-Mandeb. Moreover, the shallow shelf hosts numerous islands and fringing coral reef zones along coastal areas of the Sea. In general, the shallowest parts of Red Sea, with a depth of 50 meters, comprise $25 \%$ of its area. Some $40 \%$ is moderately shallow at depth of 100 meters. Only 15\% is considered moderately deep at a depth level of 1000 meters and $20 \%$ is the deeper than 1000 meters.

In north, Red Sea has two closed bifurcated marine features, i.e., the Aqaba and Suez gulfs. Gulf of Suez is a shallow submarine body with depth of about 50 meters. Gulf of Aqaba, by contrast, has depth ranging between 800 meters and 1800 meters. Suez Canal is a manmade civil structure linking Mediterranean Sea to Red Sea via Gulf of Sues, which was built in 1869 for modern international navigation [21], with an overall length of 193 kilometers, a depth of 180 - 205 meters and a width of 21 meters between the buoys.

In south, the width of Red Sea reduces to 30 kilometers at Strait of Bab-El-Mandeb, where Perim Island divides it into two channels in between Yemen and Djibouti. Eastern channel is about 3 kilometers wide and 30 meters deep, while the western cannel is about 25 kilometers wide and 310 meters deep. In fact, the acute narrowing at the Strait of Bab El-Mandeb poses a handicap by causing the chocking conditions for the re-flushing of the highly saline-water of the bottle-necked Red Sea marine body.

\subsection{Tectonic Setup}

Current tectonic setup of the peninsular landmass is very complex as simultaneously three tectonic forces, i.e., divergent (rifting), convergent (subduction) and shearing (transform and transcurrent faulting), are together actively in progress along peripheral areas (Figure 3).

In east, there is an active transform-cum-transcurrent right lateral fault system, known as "Owen Fracture Zone” growing and extending from Carlsberg Spreading Center of Indian Ocean towards the Makran coastal region of Pakistan passing parallel to Arabian Peninsula within the western part of Arabian Sea. The Makran coast was considered to be region of segmented subduction $[22,23]$. In northwest, the Peninsula is converging against the Mediterranean-Tethyan Mobile Belt at the rate of 2.4 millimeters/year [24,25]. Northwestern margin of the Peninsula is again subjected to the development of leftlateral transcurrent-fault system passing through the Gulf of Aqaba and Dead Sea and linking the Red Sea Rift basin to the Mediterranean-Tethyan Mobile belt.

The western margin is typically rifted and modified 


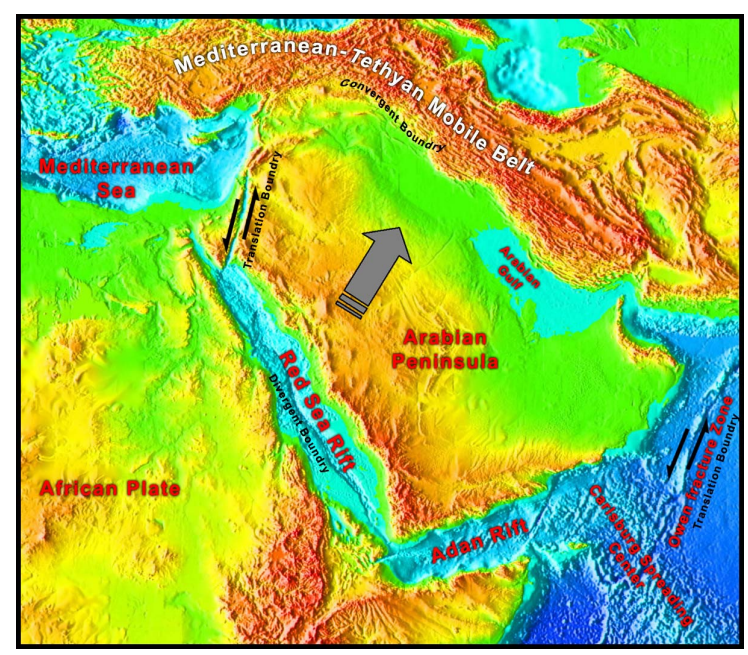

Figure 3. Map shows the configuration of earth's surface in relation to tectonic setup of Arabian Peninsula and its surrounding regions. Image data source: [15].

under the influence of the ongoing divergent tectonic processes, which cause growth of the Red Sea Rift basin $[26,27]$. Similarly, southern margin of Peninsula again is being deformed and re-modifying by divergent activities associated with the active Aden Rift. Westward, Aden Rift makes a triple junction with Red Sea and East African Rift that appears to play a major role in faster deformation of southern part of the Red Sea as evident from the Neotectonic volcanic eruption activities.

Based on Red Sea magnetic anomaly profiles, it has been estimated that since 3.2 Ma the fastest spreading rate, about $\sim 16$ millimeters/yr, occurs near latitude $18^{\circ} \mathrm{N}$, whereas the slowest rate, about $\sim 10$ millimeters/year, occurs at latitude $25.5^{\circ} \mathrm{N}$ [28]. From differential spreading rates prevailing across Red Sea, it is inferred that the coastal areas of Saudi Arabia are under constrain of pullapart-cum-shearing forces causing oblique deformation along the coastal areas that needs to be incorporated in the planning of the coastal developments.

Moreover, a model was worked out for the rift-asymmetry and continental uplift. The model shows that the eastern sides of most of the earth's rift zones have higher elevation of 100 - 300 meters that affects not only the oceanic lithosphere but also the continents to the east [29]. Same model is applicable in case of Saudi Arabia that lies on the east-side of the Red Sea Rift zone. Based on the proposed model, it is inferred that western rifted coastal belt of Saudi Arabia is accounted for ongoing vertical as well as horizontal motions causing complex structural setup.

Based on present tectonic setup of the region, it is inferred that the western and the southern rifts have separated Arabian Peninsula from the Afro-Arabian megalandmass; and the eastern and northwestern translational tectonic faulting system collectively moving or drifting the Peninsular landmass towards northeast causing enormous compression forces on western segments of the Mediterranean-Tethyan Mobile belt, like Zagros-ThrustSystem as evident from NW-trending shift of the Arabian continental landmass at an average velocity of 5 centimeters/year [30].

In present active tectonic scenario, the re-activation of pre-existed dormant fault/fracture zone(s) is conceived that may cause displacement(s) of rock units on varying scales depending upon several geotectonic parameters and as such generating micro, macro or mega earthquakes at any time. These phenomena need continuous monitoring and evaluation of such re-activations considering the presence of important civil structures, like the desalination plants developed along the coastal areas of Red Sea.

\subsection{Seismotectonic Setup}

For a long time, Arabian Peninsula was generally considered to be stable continental mass and also as one of the seismic quiescence parts of the world, but results of the present study and integrated reviews of the sporadic studies carried out during the last three decades in different parts of the Peninsula seem to call for a reconsideration of the accepted view [31]. One cannot, in fact, speak of seismic quiescence any longer, as the geo-tectonic setups of the peripheral areas and associated seismicity patterns show actively mobile deformational events under the ongoing varying tectonic processes. Moreover, it is also inferred that high magnitude disastrous intrapolate earthquakes may occur within the stable continental crust like high magnitude earthquake of New Madrid and Rann-Kutch of India [32,33]. In and around Red Sea, the seismicity activities are mainly controlled by the prevailing dominant tensional force-domain under the divergence processes between the African and Arabian plates. Thus, such high magnitude earthquake occurrence cannot be ruled out.

\section{Seismicity in and around Red Sea}

The seismic events, recorded in and around Red Sea during the last 38 years from 1973 to May 2011 [34] show that the frequency and intensity of earthquake occurrences comparatively is moderately high, but it has also been observed that the natural trend of increase in low to moderate earthquakes' occurrences more or less is the same with variation in relative calmness or the temporal gaps among high magnitude earthquakes (Table 1).

The empirical correlation, between the historical and modern earthquake occurrences for the periods of 19731983 and 1973-May 2011 (Figure 4), shows presence of distinct clustures and/or zones of high seismicity associated with Gulf of Aqaba and its intersection with Gulf of Sues and also with northern end of Red Sea. Similarly, the southern section of Red Sea also shows a complex 
Table 1. Summary of the earthquakes occurred between Lat. $8^{\circ} \mathrm{N}-34^{\circ} \mathrm{N}$ and Long. $32^{\circ} \mathrm{E}-41^{\circ} \mathrm{E}$ during periods of $1973-1983$, 1984-May 2011 and 1973-May 2011 along Red Sea and its surrounding areas. Data source: NEIC (2010).

\begin{tabular}{|c|c|c|c|c|c|c|c|}
\hline Period & Total & $\begin{array}{c}\text { Magnitude } \\
1 \text { to } 3\end{array}$ & $\begin{array}{c}\text { Magnitude } \\
3.1 \text { to } 4\end{array}$ & $\begin{array}{c}\text { Magnitude } \\
4.1 \text { to } 5\end{array}$ & $\begin{array}{c}\text { Magnitude } \\
5.1 \text { to } 6\end{array}$ & $\begin{array}{c}\text { Magnitude } \\
6.1 \text { to } 7\end{array}$ & $\begin{array}{c}\text { Magnitude } \\
7.1 \text { to } 8\end{array}$ \\
\hline 1973 to 1983 (Ten Years) & 133 & 7 & 3 & 87 & 35 & 1 & 0 \\
\hline 1984 to May 2011 (28 Years) & 1620 & 76 & 323 & 838 & 84 & 5 & 1 \\
\hline 1973 to May 2011 (38 Years) & 1753 & 76 & 326 & 925 & 119 & 6 & 1 \\
\hline
\end{tabular}

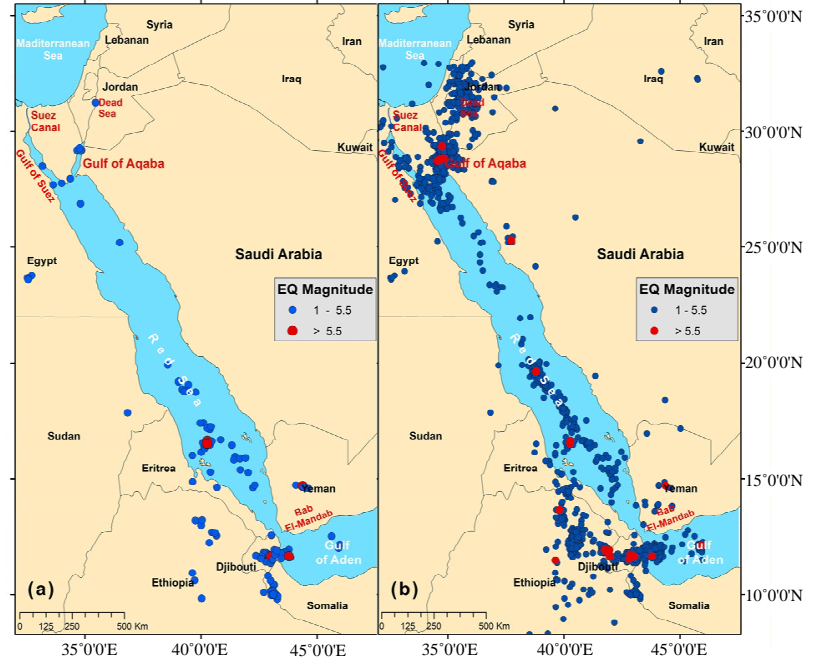

Figure 4. Comparative plots of earthquake occurrences along Red Sea and its surrounding areas from 1973 to 1983 (a: left frame) and from 1973 to May 2011 (b: right frame).

pattern of the earthquake occurrences. Moreover, the occurrence frequancy of modern seismic events has increased about ten-times in comparison to historical earthquakes.

The seismicity trend along axis of Red Sea bifurcates into two distinct south-trending branches near latitude $17^{\circ} \mathrm{N}$. One branch extends southeast along axial trough of Red Sea and the other branch strikes SSW and joins another two earthquake zones, one that comprises of northern earthquakes of East African Rift System, and the other one that continues eastward to Gulf of Aden. Two seismicity zones originating from latitude $17^{\circ} \mathrm{N}$ in Red Sea and the seismicity zone west of Gulf of Tadjurah in south of Bab-el-Mandeb, together surround a relativley aseismic area that may represent a subaerial microplate [35]. Likewise, the exial part of the Red Sea rift, between latitudes $20^{\circ} \mathrm{N}$ and $17^{\circ} \mathrm{N}$ also shows significant increase in seismicity activities in relatively wider zone as compared to northern part of Red Sea between $25.5^{\circ} \mathrm{N}$ and $20^{\circ} \mathrm{N}$ latitudes. It is inferred that the complex seismicity trends associated with triple junction of three rifts and volcanic activities may create disastrerous conditions for the only narrow outlet at Bab-el-Mandeb resulting partial or total closer of Red Sea.

The inferences drawn presently have also been sup- ported by salient sporadic studies that were carried out during the last three decades in different parts of the peninsula [36-41]. Moreovre, the seismicity activities have significantly extended landward within Saudi Arabia, which also indicates reactivation of pre-existed faults of the Arabian Shield.

\subsection{Volcanic Activities in Red Sea}

General shape of Red Sea is like an arrow pointing to western end of Aden Gulf. Each component of Red Sea geometry (i.e., width, shelf, shelf-slope, width \& depth of axial trough etc.) is teppering southward to Perim island at Strait of Bab-el-Mandeb (Figure 2). It is interesting to observe that the teppred end is the only opening for Red Sea to link with Indian Ocean via Gulf of Aden whereas northern end has two closed narrow and smaller gulfs, i.e., Suez and Aqaba, before it may have linked with Meditranean Sea.

Modern reactivation of volcanic eruptions has been observed on either ends of the Red Sea. In northern section, vigorous seismicity occurred associated with the onland Lunayyir Volcano within coastal belt, where nineteen earthquakes of magnitude ranging between 4 and 5.4 and a swamp of more than 30,000 micro-earthquakes occurred in 2009 [42]. There was no eruption of lava, except a long fissure observed on the ground with escaping of gasses. Apparently, so far no prominent volcanic activity has been reported in this part of Red Sea axial trough.

On the other hand, a series of volcanoes has been reported occurring within axial trough in southern part of Red Sea from latitude $16^{\circ} \mathrm{N}$ to $12^{\circ} \mathrm{N}$ in addition to onland volcanism on either side at the southern most end of Red Sea. The most significant tectonic setup within the teppered part of the Sea is the existance of a most active triple junction of three rifts, namely Red Sea Rift, East Afirican Rift and Aden Rift. Among these rifts, East African Rift is the most hazardous and more active one. The ongoing tectonic processes have caused prominent volcanic activities since Neogene era in and around the gateway of Red Sea. As a result of volcanogeneic events, a number of islands have appeared in the area. This has a significant impact on the geometry of the sourthern most part of Red Sea. The impact of active volcanism seems to 
cause more enhansment of high salinity by blocking outflow as well as inflow of seawater between Red Sea and Aden Gulf.

At Strait of Bab-el-Mandeb, there is a volcanic island, Perim, with a surface area of $13 \mathrm{~km}^{2}$ rising to an altitude of 65 meters. It bifucates the narrowest width of Red Sea. It has been reported that the Perim volcanic eruptions had blocked Strait of Bab-el-Mandeb sometime in the geological history and consequently Red Sea evaporated to an empty hot dry salt-floored sink [43]. About 356 kilometers north of Perim volcanic island, there is another tiny volcanic island, known as Jabal Al-Tahir Island at latitude $15.5^{\circ} \mathrm{N}$ and longitude: $41.83^{\circ} \mathrm{E}$ (Figure 5). Volcogenically, the region between Perim and Tahir volcanic islands is currently active along southern part of Red Sea.

The latest eruption of Tahir volcano occurred on September 30, 2007. Enormous lava oozed out over its flanks, releasing a dense white cloud of volcanic ash (Figure 5). It was reported that several earthquakes ranging from 2.0 - 3.6 magnitudes occurred for about two weeks near the island [44], but no earthquake of higher magnitude was reported in the vicinity of At-Tahir Island during pre or post-erupting period from August to October 2007 as per record of USGS/NEIC. However, four earthquakes, ranging of 4.2 - 4.8 magnitudes, were recorded during period from 1994 to 1997 in the vicinity of 25 kilometers radius according to the USGS/NEIC catalog. The historical record shows that there have been several previous known eruptions of the volcano including a possible one in 14th, 18th and 19th centuries. The last major eruption was in 1833 [45]. It has been inferred that the latest eruption is

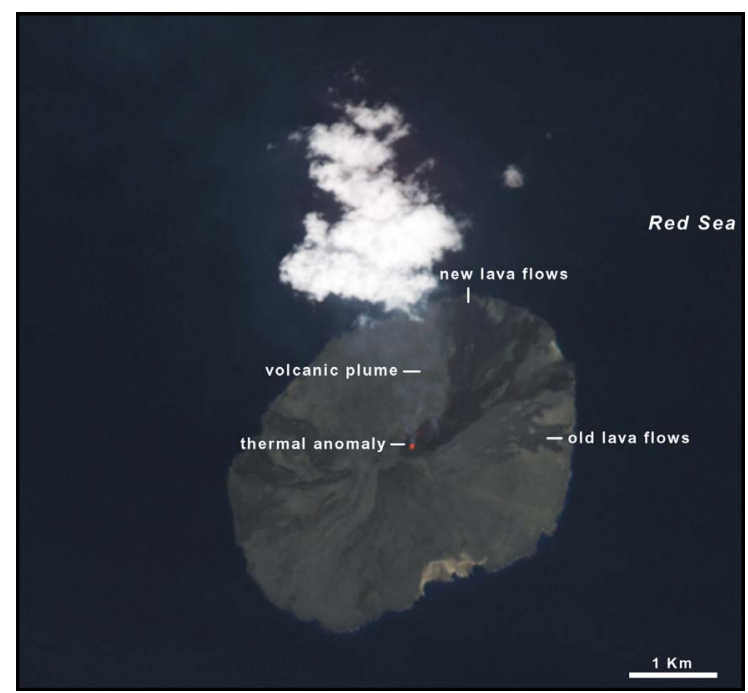

Figure 5. ASTER satellite image, acquired on October 8, 2007, shows eruption of At-Tair volcano, its lava flowing down its flanks and releasing a jet of volcanic ash cloud after 8 days of volcanic activity. Source:

http://earthobservatory.nasa.gov. a continuation of activity on the island, where explosive eruptions were recorded in the eighteenth and nineteenth centuries. At-Tahir Island is the northern most known Holocene volcano in southern part of Red Sea.

In contrast to single tiny At-Tahir volcanic island, there is a larger group of 10 small islands, aligned in the NNW-SSE direction parallel to Red Sea, spreading over 5 kilometers long area that rises from a shallow platform in the rifting trough. The largest island is Jebel Zubair Island, which is a shield volcano at latitude of $15.05^{\circ}$ and longitude of $42.17^{\circ}$. This volcano, located about 66 kilometers south of At-Tahir volcano, was erupted in 1824. Eruptions similar to the late-stage explosive and effusive activities were also reported in 19th century associated with other three islands of the Zubair islands' group. They are located SW and NW of the main Zubair Island and a small island at the upper left (Figure 6).

In between Zubair Group of volcanic islands and Perim volcanic island at 150 kilometers from either sides, there is a belt of volcanic islands, known as Zukur-Hannish group of volcanic islands, aligned in northeastsouthwest direction that is a unique and anomalous orientation obliquely across the axial trough of Red Sea

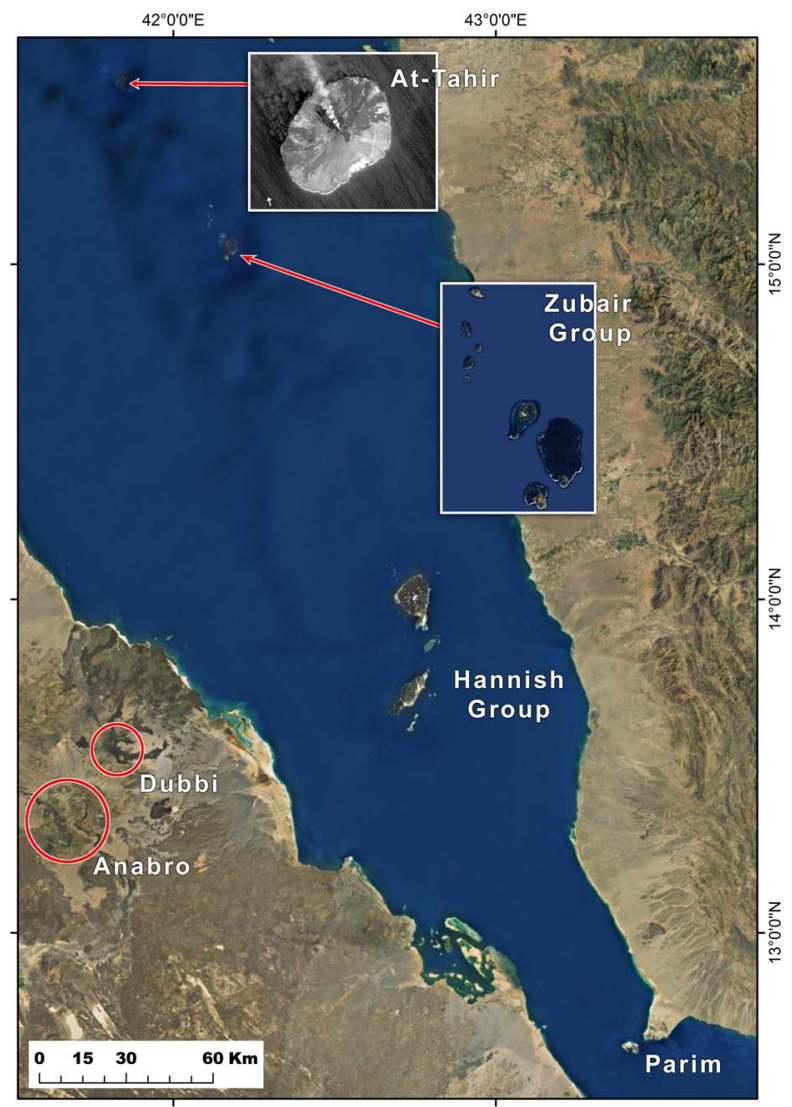

Figure 6. Map shows the relative locations of the groups of active volcanic islands aligned parallel and as well obliquely across the axial trough of southern Red Sea. Sources: ESRI, Google Earth, NASA Earth Observatory. 
(Figure 6). This group consists of many islands of varying sizes from tiny to large aerial dimensions. Zukur and Hannish, are the larger ones. The bathymetry data show anomalous rise striking in NE-SW direction across the general orientation of Red Sea basin. It appears that the alignment of this volcanic zone coincides with the alignment of East African Rift as is evident from the latest eruptions of Nabro Volcano in 2011 [46].

On 12th June 2011, the Anabro (Nabro) volcano, in northern part of Eritrea at latitude $13.37^{\circ} \mathrm{N}$ and longitude $41.70^{\circ} \mathrm{E}$, re-erupted within tectonically active Afar Triangle along the western coast of Red Sea. MODIS image (Figure 7) acquired by NASA Aqua-satellite captured the jetting out ash-plume more than $15 \mathrm{~km}$ into the sky [47]. During eruption process, sixteen earthquakes of moderate magnitude, ranging from 4.3 $\mathrm{M}$ to $5.5 \mathrm{M}$, were occurred in a radial pattern around the volcano [48]. Nabro volcano is part of East African rift complex that has several nested calderas [49]. In this part, the African continent is slowly pulling apart due to tectonic plate movements in conjunction with Red Sea and Aden rifts causing complex tectonic/geomorphical changes along the coastline.

Most recently, a new surtseyan volcanic eruption occurred on December 19, 2011, at Az-Zubair archipelago. Exploding-lava eruption has been reported rising to a height of 30 meters [50]. MODIS image of 23-December2011, showed a dense plume rising from a shallow submarine horizon. The current activities in Red Sea comprised of more than an eruption, because successive emergence of new island is also observed comparing different temporal images (Figure 8) of 7-January-2012, 23-December-2011 and October-2007 [51,52].

The study shows that recent potentially active volcanic island areas in southern part of Red Sea are the Jebel AtTair, Zubair Islands, Hannish-Zukur islands, Perim volcanic island and Dubbi-Nabro volcanic group of northern Afar rift-zone. Based on volcanic-trends, it is inferred that the eruptive activities initiated at southern end may

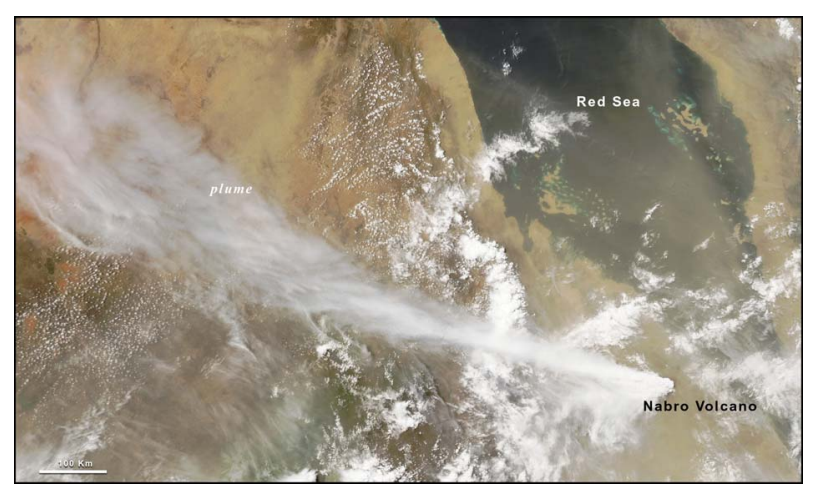

Figure 7. Satellite image shows the eruption of the Anabro (Nabro) volcano on June 12, 2011, along the western coast of the Red Sea. Source: [47].

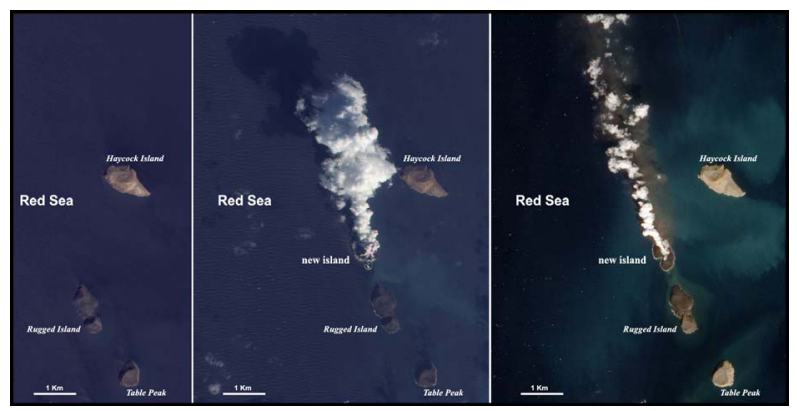

Figure 8. Emergence of new island at Az-Zubair archipelago in the axial part of Red Sea can be seen on larger scale on image (right) captured by NASA's EO-1 satellite on January 7, 2012 as compared to minor scale on December 23, 2011 (Center) in relation with image (left) captured on October 24, 2007, which does not show any break in Red Sea water indicating any kind of emergence. Source: [51, 52].

cause significant tectonic deformations in response to anticlockwise rotation of Arabia Peninsula relative to Africa and, as an eventual consequence, Red Sea axial trough may die out southwards owing to tectonically deformed structures and the volcanic fills from the potential volcanic hot-spots as described above. Such a situation indicates drastic suffocation and stagnancy of seawater in future.

\subsection{Geotectonic Processes Causing High Salinity in Red Sea}

Worldwide, the salinity of the seawater averages about $35 \%$, but Red Sea is among the hottest and most saline seawaters in the world with surface seawater temperature of more than $30^{\circ} \mathrm{C}$ in summer and about $40 \%$ average salinity that varies from north ( 46\%) to south ( 38\%) [53,54].

The main factors, contributing high salinity of seawater in Red Sea, have been described as high rate of evaporation and low precipitation under arid harsh climate, no permanent inflowing coastal rivers or streams, partially isolation of Red Sea from the open ocean and other miscellaneous land-based urbanizational and industrial activities in the Red Sea coastal cities [53-61]. No doubt, these inferences may be some of the common factors for increase of salinity, but during the present study, for the first time, the presence of naturally generating enormus hot brines and perculation of the avapotires are taken into the consideration. It seems to be the permanent renewable source to abnormaly high salinity to Red Sea. As these major renewable sources, enhancing high seawater salinity in Red Sea, were not considered during previous studies in relation to seawater desalination. Some of the archieve studies have been reviewed related to the geotectonic renewable-sources and their findings incorporated in the present study. 
Three separate pools of hot brine were identified along axial trough of Red Sea based on bathymetric and geophysical investigations [62]. Similarly, the most prominent hydro-geothermal activities were investigated in Atlantis-II Deep about 100 kilometers in west of the Jeddah coast [63]. From mid-1960 to late-1990, more than 20 geomorphological depressions filled with highly concentrated brines were identified in central rift zone of Red Sea [64]. These interpreted brine-pools consist of four convective layers, among them the lower convective layer was inferred to be the hottest and the saltiest brine.

Results of the Red Sea deep-drilling exploration reveal the presence of hot-brine layers underlain by metalliferous system $[65,66]$. The periodic discharges of hot-brine were described from eastern side of the largest and deepest part of the trough [62]. But integrated model (Figure 9) based on models of $[67,68]$, shows consistent percolation of hot dense brine from eastern as well as western sides of the deepest parts of the axial trough.

It was also inferred that there is a forced convection cell where salts precipitate and accumulate immediately above the magma chamber located beneath axis of the rift [69], and as such, hydrothermal "out-salting" is the main cause of dense, warm brines accumulating in central portion of Red Sea (Figure 9). Moreover, the hot "geysers" of saturated brines have also been identified in Atlantis-II Deep of Red Sea and inferred as originating from re-dissolution of salts accumulated in underground fracture systems.

Numerous specific studies of buried hydrothermal systems have conclusively shown that seawater circulates deep into sedimentary formations and also underlying oceanic crust. It is also observed that the seawater interacts with another geochemical reservoir, like in the case of Miocene evaporites underlying within the entire length of Red Sea [70]. The proposed model elucidates that sea-

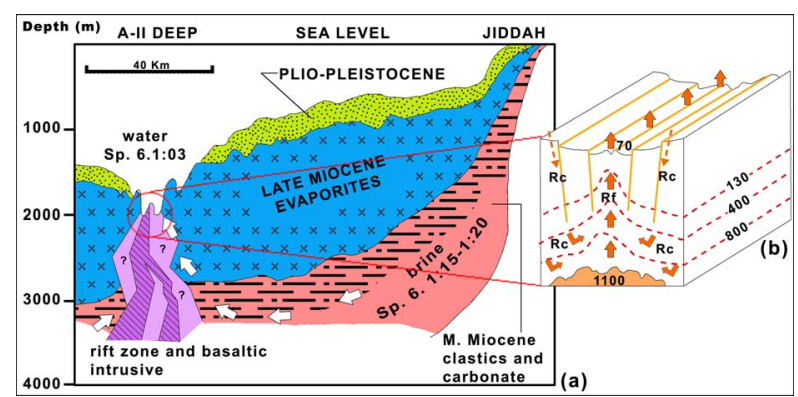

Figure 9. Schematic models show the consistently renewable major salt-contributors to Red Sea; (a) Shows the detailed view of flanking recharge trends as a result of normal seawater reaction with subsurface Red Sea Miocene evaporites (after Manheim, 2007); (b) Shows updated conceptual model [69] based on inferred conditions by $[85,86]$. Legend (b): Rc $=$ Recharge zones, $\mathbf{R f}=$ Reflux zone. The broken lines are isotherms at $130^{\circ} \mathrm{C}, 400^{\circ} \mathrm{C}$, and $800^{\circ} \mathrm{C}$. Temperature at seafloor is $70^{\circ} \mathrm{C}$, and at magma chamber $1100^{\circ} \mathrm{C}$. water of normal salinity penetrates into subsurface and circulates downward through evaporites, where it becomes strongly enriched in salt. The fluid moves horizontally along fissures through the newly formed oceanic crust and interacts with the young basalts.

Based on above mentioned studies, three renewable zones of the Red Sea trough sub-seabed system have been anticipated to possess the potential for being meganatural salt-contributors. First, there are warm brine-pools on seafloor at the deeper bottom parts of axial-rift-trough where salt precipitates due to cooling at $70^{\circ} \mathrm{C}$. Second, salt-rich contributor represents the central reflex at the rifting where salt precipitates due to boiling. Third, one of the major contributors of salt-enrichment are the flanking recharge zones, in which normal seawater reacts with subsurface Miocene evaporites underlying the entire length of Red Sea.

\subsection{Limitations for Re-Flushing of Highly Saline Red Seawater}

The northern end of Red Sea has no direct natural link to Mediterranean or any other sea except the manmade Sues Canal. The narrow basin of Red Sea has just one tenuous indirect link to the Indian Ocean through Aden Gulf via Strait of Bab-el-Mandeb. The narrowest cross-section of Red Sea is 32 kilometers wide in vicinity of Perim Island (Figure 10). But in north of Perim Island, the passage of the sea, particularly the relative deep channel, is deformed by the presence of northeast-southwest trending series of islands, known as "Hannish Islands", across axial trough of Red Sea in between Eritrea and Yemen. The bathymetry data also show rising-trend of the deep channel of Red Sea on northern and southern sides of the

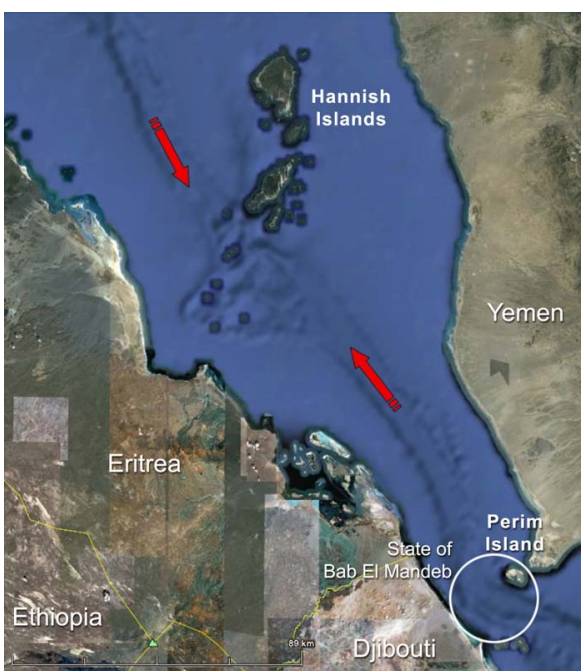

Figure 10. Group of Hannish islands aligned obliquely across the southern shallow part of the Red Sea axial trough shows the anomalous up-rising trend and deforming of the deepchannel of the trough. Source: Google Earth. 
Hannish islands' complex as shown by "arrows”. The uprising tectonic interference may have caused significant chocking for both interactive outflow and inflow of surface seawater in general and the deep seawater in particular between Red Sea and Aden Gulf. It was observed that the shallowest projection over which the deep water must pass is at a depth of 137 meters in west of main Hannish Island situated about 150 kilometers NNW of Perim [71]. In the southern part, however, relatively deeper Red Sea channel shows a triangular shaped braded channel about 12 kilometers wide flanked by broad shelves with average depth of 50 kilometers on either sides.

The prevailing submarine geomorphic features and geotectonic uprising indicate the restricted interactive high salinity water outflow of Red Sea to Aden Gulf and the low salinity water inflow of Aden Gulf to Red Sea. Moreover, seasonal variability of flow across Bab-elMandeb was also observed as a result of onset of periodic monsoon climate [71]. During winter season, the warmer, fresher water flows into Red Sea in upper surface layer and the cooler, saltier water flows into Aden Gulf in lower layer. But in summer, the exchange-conditions become hazardous through Bab-el-Mandeb as the high salinity outflow is nearly arrested, the flow in surface layer is reversed, and the intermediate water from Aden Gulf flows into Red Sea between the two outflowing layers.

\section{Anthropogenic Hazards}

Like natural hazards, there are numerous adverse activities those may cause degradational impact on the future sustainability of water-supply from the seawater-desalination facilities directly and/or indirectly with passage of time and/or within unpredictable sudden shorter timespan depending on the specific nature of the individual threat. The salient anthropogenic such threats, encountering in Red Sea, may include 1) accidental oil spills, 2) international conflicts, 3) heavy shipping traffic causing quality deterioration of marine waters, 4) accidental and/ or sabotage activities causing uncalled for sudden and huge damages to desalinated-water supply network, 5) terrorist activities, 6) ever-increasing contribution of enormous brine discharges from the world's largest networks of the desalination plants, 7) thermal pollution due to discharge of hot-water that being used for cooling of certain parts of the huge industrial machines, 8) discharges of untreated and/or partially treated municipal and industrial wastes, 9) emergency maintenances replacement of damaged pipelines of water-supply network systems, 10) recurrent increase in required energy, and costs for desalinated water-production and maintenance of the plants against the desalination of anticipated highly deteriorated seawater in near future, 11) total dependency on the outsourced desalination technology in the country.
In the last two decades, numerous research studies have been carried out in regards to above mentioned anthropogenic activities causing adverse environmental impact on the Red Sea water, its biodiversitified echo-systems and operational activities of the desalination plants [12,53,69,71-82].

In relation to the brine discharges from the desalination plants along Red Sea, the statistical data of Jeddah desalination plant is taken into consideration as an example. During 2011, the total inlet-flow has been estimated $6800 \mathrm{~m}^{3} /$ hour (60 million $\mathrm{m}^{3} /$ year) and out of this intake the production flow-rate was $2720 \mathrm{~m}^{3} /$ hour (24 million $\mathrm{m}^{3} /$ year) and rejected flow-rate of brine was recorded $4080 \mathrm{~m}^{3} /$ hour or 36 million $\mathrm{m}^{3} /$ year (M. Ettwadi, Personal Communication, December 2011). The production and rejected flow rate are $35 \%$ and $65 \%$ of the total inlet-flow. Based on the equation, i.e., total inlet-flow $=$ production-flow + rejected-flow, the rejected concentrated brine discharging from all the plants, commissioned along the Red Sea in Saudi Arabia, has been estimated to the tune of about 3002.5 million $\mathrm{m}^{3} / \mathrm{year}$ by using the total production-flow of 3.29 million $\mathrm{m}^{3} /$ day or 1201 million $\mathrm{m}^{3} /$ year. These statistics of concentrated brine-discharges indicate that the major part of concentrated saline water is being discharged back into the sea. The concentration of the desalination brines is normally around double that of natural seawater. In case of Red Sea, the salinity increase of about $0.22 \mathrm{~g} / \mathrm{L}$ in 1996, 0.49 $\mathrm{g} / \mathrm{L}$ in 2008 and $1.16 \mathrm{~g} / \mathrm{L}$ by the year 2025 were estimated as consequence of brine discharge from desalination [12]. The fact should not be ignored in this scenario that Red Sea is already the most salty body among other marginal seas of the world. It is inferred that the salinity will further significantly be increased in Red Sea in general and particularly where the rejected brines are being discharged. Thus, as a result, irreversible seawater degradation is anticipated causing damage to the aquatic life and the consequent hazardous conditions to desalinating processes. The resulted environmental scenario will ultimately increase the cost of maintenance of the desalination plants and the socio-economic crises to fishing industry and other related disciplines.

Likewise, Red Sea is also suffering from oil pollution along most of its coast as well as in its offshore waters. An important marine transport route between Europe and the Far East passes through the Red Sea particularly for the carriage of oil and other commodities. Most oil spills in this region have been the result of operational discharges, equipment failure and groundings. Despite the low occurrence of major accidents within the region, the high volume of shipping results in chronic pollution in the form of tarballs arriving on the shorelines [83]. The coast of Saudi Arabia between Jeddah and Yemen is heavily tarred at places. The Egyptian coast near offshore 
oil fields of Gulf of Suez is similarly affected by oil discharges. For example, the latest oil spill has occurred in Red Sea during June-2010, which was considered to be the largest offshore spill in Egyptian history. The spill polluted around 100 kilometers of coastline due to a leakage from an offshore oil platform at Jebel al-Zayt north of Hurghada [84].

The impacts of the long \& short terms or the sudden occurring anthropogenic threats, identified during the present study, need to be considered integrating with the natural hazardous events for developing a model of sustainable water management system. Unless, a balance in the priority among different disciplines of water resources is not maintained, the sustainable establishment of effective and better interactive water-supply network is not anticipated for future. Thus, the alternate strategic water management plans are imperative parallel to the fast development of seawater desalination options in the country.

\section{Discussion}

During about last two decades, the investor and policy makers are focusing on the development of desalination technologies, especially in arid and semiarid areas of Middle East that have rich-economic conditions and the technology developing sector advocating the interest in desalination technologies. Looking at the present trend for water supply from seawater against the development of other on-land traditional resources, a question arises whether the desalination technologies are the answer to the world water crises.

It looks very simple that "desalination" involves the process of removing salt from the seawater to produce drinkable water, but the case is not so simple from present study. The construction, operation and maintenance costs of seawater desalination are at many folds expensive as compared to traditional sources. In addition to the high costs, the technologies are not environmental friendly. The removing salt from seawater produces enormous brine concentrates with several toxic contaminants too, which have affected marine life when dumped back into the sea causing irreversible damage to the marine eco-system. There are other several demerits of desalination related to human health, consumption of enormous fossil fuel and/or energy from other sources, causing thermal pollution to seawater, and emitting green house gases contributing to global warning.

Though, innovations in desalination technologies do offer some promise to minimize some of these problems, but the impacts of the natural and the anthropogenic hazards cannot be ruled out as the geo-environmental ongoing-processes, identified during the study, indicate the vulnerability regarding the strategic developments, inclusive of huge desalination plants, in the coastal areas of
Saudi Arabia along the Red Sea. Some of the natural as well as anthropogenic threats may cause sudden disastrous environments to the desalination facilities and/or some other may cause slow and steady damages to the presently prevailing conducive environments of the seawater desalination options.

In turn, it is anticipated that absolute dependency on the seawater desalination for the supply of potable water may not be adequate without the parallel development of the land-based "strategic water management plan" on the equal priority. In this connection, some of the alternate options for the sustainable availability of potable water in the areas/cities along the coastal belt of Red Sea are also imperative to be equally considered parallel to the development of seawater desalination in Saudi Arabia. The proposed management efforts should include the strategic groundwater exploration \& development program as the western coastal belt of Saudi Arabia along Red Sea has numerous "wadi drainage-systems" running across the rifted margin of the Arabian Shield and showing bright prospects of groundwater in fault/fracture zones, a standby "water supply mixed with groundwater system" or the "supplementary brackish water supply" should be made readily available to provide the urban areas with drinking water in emergency situations, the adoption of conservation methodologies in water-use national plan, the development of strategic large water harvesting \& storage structures, the inter-linkage of desalination plants, and the continuation of detailed studies in and around the coastal and eastern Shield areas.

\section{Conclusions}

Red Sea, especially in its southern and northern parts, exposed to relatively significant geotectonic activities related to the seismicity, volcanism, and differential movements of Arabian Plate under the Red Sea-floor-spreading processes deforming geomorphologic geometry of the coastline and submarine configuration gradually and under some geologic phenomena sudden at any time in the future.

Moreover, the increase in the salinity of the Red Sea water will also intensify in the time to come and expectedly will cause the further deterioration of the seawater quality, in turn which will affect directly or indirectly the operational activities of the desalination plants.

Manifestations of geo-hazards trends suggest that our arid region has already entered in a period of complex geodynamic disturbances and manmade multidisciplinary odd \& non-environmental-friendly developments under internal as well as the global crossed-interests. The hazards arising from such developments should not be ignored, especially in regard to the desalination plants and the uninterrupted water supply from them.

In view of the natural \& anthropogenic hazards, posed 
to stability of Red Sea environment and basic condition of water scarcity under which Arabian Peninsula has labored for centuries, only a balanced, integrated water supply policy is likely to safeguard the minimum needs of population, which has presently and will be increasing exponentially in long term.

Disaster preparedness options, envisaged to restore water supply to the community in case of any emergency, should be given equal priority as presently practicing in the case of the accelerated development of desalination capabilities.

\section{Acknowledgements}

Authors are highly thankful to Prof. Abdulrehman Obaid Al-Youbi, Vice President for Educational Affairs, Prof. Adnan Zahid, Vice President, Higher Education \& Research, and Prof. Yousef Al-Turky, Dean of Scientific Research, King Abdulaziz University, for their complete support for the smooth execution of the research study. Special thanks are paid to King Abdulaziz City for Science \& Technology (KACST) to provide financial support (Grant \# 8-WAT 140-3) for the project work. Authors are grateful to American Geophysical Union (AGU) to provide an opportunity to present the results of research as Poster-NH31A-1526 in AGU 2011 Fall Meeting at San Francisco, CA.

\section{REFERENCES}

[1] Preussag, “Company History-Preussag Arabia,” 2011. http://preussag.com.sa/company_history.html

[2] E. Lee, "Saudi Arabia and Desalination-Harvard International Review,” 2010. http://hir.harvard.edu/print/pressing-change/Saudi-arabiaand-desalination-0

[3] Ameinfo, "Seawater Desalination Leads Response to Global Water Crisis,” 2009.

http://www.ameinfo.com/215302.html

[4] MOEP, "Saudi Statistical Yearbook 2005,” Saudi Ministry of Economy \& Planning, Riyadh, 2005.

[5] Zawya, "Census Shows Saudi Arabia's Population at More than 27 Million,” 2010. http://www.zawya. com/story/ZAWYA20101124035437/

[6] O. S. Aburizaiza, "Proposed Solutions to Solve Crowding Problems in Holy Places in Saudi Arabia," Al-Sitten Publishers, Jeddah, 2005.

[7] J. R. Hunter, "A Review and Theoretical Interpretation of Previous Observations," Proceedings of the 1st Gulf Conference on Environment and Pollution, KISR, Kuwait, 1982.

[8] F. Ahmad and S. A. R. Sultan, “Annual Mean Surface Heat Fluxes in the Arabian Gulf and the Net Heat Transport through the Strait of Hormuz," Atmosphere-Ocean, Vol. 29, No. 1, 1991, pp. 54-61.

doi:10.1080/07055900.1991.9649392
[9] A. S. Bower, H. D. Hunt and J. F. Price, "Character and Dynamics of the Red Sea and Persian Gulf Outflows," Journal of Geophysical Research, Vol. 105, No. C3, 2000, pp. 6387-6414. doi:10.1029/1999JC900297

[10] F. A. Yamani, "Protecting the Gulf's Marine Ecosystems from Pollution,” In: A. H. Abuzinada, et al., Eds., Importance of the Freshwater Influx from the Shatt Al-Arab River on the Gulf Marine Environment, Birkhauser, Verlag, 2008.

[11] A. A. Muhairi, H. Ghedira, H. A. Ahmad, et al., "Exploring the Potential of MODIS Visible and Thermal Channels in Monitoring and Assessing the Impact of Desalination Plant Discharges in the Arabian Gulf," Proceeding of IEEE International Geoscience and Remote Sensing Symposium, Vol. 3, 2009, pp. 357-360.

[12] R. A. I. Bashitialshaaer, K. M. Persson and M. Aljaradin, "Estimated Future Salinity in the Arabian Gulf the Mediterranean Sea and the Red Sea, Consequences of Brine Discharge from Desalination," International Journal of Academic Research, Vol. 3, No. 1, 2011, pp. 133-140.

[13] O. S. Aburizaiza, N. A. Zaigham, Z. A. Nayyar, et al., "Identified Natural Hazards May Cause Adverse Impact on Sustainability of Desalination Plants in Red Sea," Proceedings of AGU Fall Meeting, AGU, Abstract \# NH 31A-1526, 2011.

[14] NEIC, “USGS Earthquake Hazards Program,” 2010. http://earthquake.usgs.gov/earthquakes/eqarchives/epic/

[15] NGDC, “Marine Geol. \& Geophysics: NOAA,” 2011. http://www.ngdc.noaa.gov/mgg/image/2minrelief.html

[16] Indiandia, "Introduction to Desalination: Indian Desalination Association,” 2011. http://www.indaindia.org/intro_desalination.htm

[17] IDA, "IDA Worldwide Desalting Plant Inventory, No. 19 in MS Excel Format," Media Analytics Ltd., Oxford, 2006.

[18] IDA, "IDA Worldwide Desalting Plant Inventory, No. 20 in MS Excel Format,” Media Analytics Ltd., Oxford, 2008.

[19] J. T. Kotilaine, "GCC Water Resources,” NCB CAPITAL News Letter, 2009.

[20] I. T. Bleninger and G. H., Jirka, "Environmental Planning Prediction and Management of Brine Discharges," Rep. MEDRC-07-AS-003, Middle East Desalination Research Center, Muscat, 2010.

[21] RAFIMAR, "Suez Canal: International Multimodal Transport,” 2011. http://www.rafimar.com/homepage/suez_canal.html

[22] N. A. Zaigham, "Bela Ophiolites and Associated Mineralization in Southern Part of Axial Belt of Pakistan,” Ph.D. Thesis, University of Karachi, Karachi.

[23] N. A. Zaigham and M. Ahmed, “A Segment Subduction of Arabian Oceanic Plate verses Western Margin of Indo-Pakistan Subcontinental Plate,” Ofioliti, Vol. 25, No. 2, 2000, pp. 67-73.

[24] D. Hatzfeld, M. Tatar, K. Priestley, et al., "Seismological Constraints on the Crustal Structure Beneath the Zagros Mountain Belt (Iran),” Geophysical Journal International, 
Vol. 155, No. 2, 2003, pp. 403-410. doi:10.1046/j.1365-246X.2003.02045.x

[25] P. Agard, J. Omrani, J. Jolivet, et al., "Convergence History across Zagros (Iran): Constraints from Collisional and Earlier Deformation,” International Journal of Earth Sciences, Vol. 94, No. 3, 2005, pp. 4501-419. doi:10.1007/s00531-005-0481-4

[26] J. R. Vail, "Pan African (Late Precambrian) Tectonic Terrains and the Reconstruction of the Arabian Nubian Shield,” Geology, Vol. 13, No. 12, 1985. pp. 839-842. doi:10.1130/0091-7613(1985)13<839:PLPTTA>2.0.CO;2

[27] W. Bosworth, P. Huchon and K. McClay, "The Red Sea and Gulf of Aden Basins," Journal of African Earth Sciences, Vol. 43, No. 1-3, 2005, pp. 334-378. doi:10.1016/j.jafrearsci.2005.07.020

[28] D. Chu and R. G. Gordon, "Current Plate Motions across the Red Sea," Geophysical Journal International, Vol. 135, No. 2, 1998, pp. 313-328. doi:10.1046/j.1365-246X.1998.00658.x

[29] C. Doglioni, E. Carminati and E. Bonatti, "Rift Asymmetry and Continental Uplift,” Tectonics, Vol. 22, No. 3, 2003, pp. 1-8. doi:10.1029/2002TC001459

[30] P. Nehlig, A. Genna, F. Asfirane, et al., "A Review of the Pan-African Evolution of the Arabian Shield," GeoArabia, Vol. 7, No. 1, 2002, pp. 103-124.

[31] E. G. Triep and L. R. Sykes, "Catalog of Shallow Intracontinental Earthquakes,” 2011. http://www.ldeo.columbia.edu/seismology/triep/intra.expl .html

[32] A. C. Johnston and L. R. Kanter, "Earthquakes in Stable Continental Crust,” Scientific American, Vol. 262, No. 3, 1990, pp. 68-75. doi:10.1038/scientificamerican0390-68

[33] N. A. Zaigham, "Folds and Faults of Earthquakes. Science-Dot-Com, Magazine of the Daily Dawn," Daily Dawn, Karachi, 8 June 2001, pp. 1-3.

[34] Earthweek, "Eruptions Continue at Red Sea Volcano," 2011. http://www.earthweek.com/online/ew071214/ew071214f. html.

[35] X. LePichon and J. Francheteau, “A Plate Tectonic Analysis of the Red Sea-Gulf of Aden Area," Tectonophysics, Vol. 46, No. 3-4, 1978, pp. 369-406 doi:10.1016/0040-1951(78)90214-7

[36] H. M. Merghelani and S. K. Gallanthine, "Microearthquakes in the Tihamat-Asir Region of Saudi Arabia," Bulletin of the Seismological Society of America, Vol. 70, No. 6, 1980. pp. 2291-2293.

[37] N. N. Ambraseys and C. P. Melville, "Evidence for Intraplate Earthquakes in Northwest Arabia," Bulletin of the Seis-mological Society of America, Vol. 79, No. 4, 1989, pp. 1279-1281.

[38] Z. H. El-Isa and A. A. Shanti, "Seismicity and Tectonics of the Red Sea and Western Saudia," Geophysical Journal International, Vol. 97, No. 3, 1989, pp. 449-557. doi:10.1111/j.1365-246X.1989.tb00515.X

[39] A. BinFayez, "Microseismic Study for Central Part of Saudi Arabia," Proceedings of AGU Spring Meeting,
New Orleans, 23-27 May 2005.

[40] M. M. Al-Saud, "Seismic Characteristics and Kinematic Models of Makkah and CENTRAL Red Sea Regions Saudi Arabia,” Proceedings of EGU General Assembly, Vienna, 19-24 April 2009, p. 11876.

[41] Reuters, "Two Tremors Hit Saudi Volcano Region-No Injuries," 2009. http://www.alertnet.org/thenews/newsdesk/LJ727376.htm

[42] C. Q. Choi, “Ancient Volcanic Field Reawakens in Saudi Arabia. The Christian Science Monitor,” 2010. http://www.csmonitor.com/layout/set/print/content/view/ print $/ 328200$

[43] Wikipedia, “Perim,” 2011. http://en.wikipidia.org/wiki/perim.

[44] Z. Al-Alaya’a and A. A. Oudah, “At Least 3 Dead after Volcano Erupts on Yemeni Island,” 2007. http://www.yobserver.com/front-page/10013032.html

[45] BBC, "Volcano Erupts on Red Sea Island," 2007. http://news.bbc.co.uk/2/hi/7021596.stm

[46] Ethiopian Review, "Eritrea-Picture of the Eruption at Nabro Volcano,” 2011.

http://ethiopianreview.com/forum/viewtopic.php?f=2\&t= 28695\#p156241

[47] J. Schmaltz, “Eruption at Nabro Volcano,” 2011. http://earthobservatory.nasa.gov/NaturalHazards/view.ph p?id=50988

[48] GVP, “Global Volcanic Program, Volcanic Activity Report, Smithsonian, USGS Weekly Volcanic Activity Report," 2011. http://www.volcano.si.edu/reports/usgs/index.cfm\#nabro

[49] Volcano Discovery, “Dubbi Volcano,” 2011. http://www.volcanodiscovery.com/dubbi.html

[50] A. Vervaeck, "Surtseyan Eruption along the Coast of Yemen Forms a New Island-New Satellite Image,” 2011. http://earthquake-report.com/2011/12/29/surtseyan-erupti on-along-the-coast-of-yemen-forms-a-new-island-today-e ruption-cloud-stain/

[51] M. Scott and J. Allen, "Volcanic Activity in Red Sea, Natural Hazards,” 2011.

http://earthobservatory.nasa.gov/NaturalHazards/view.ph p?id=76801

[52] R. Simmon, "New Volcanic Island in Red Sea, Natural Hazards," 2012.

http://earthobservatory.nasa.gov/NaturalHazards/view.ph p?id=76911

[53] A. W. Chiffings, "A Draft Marine Protection Area System Plan for the Kingdom of Saudi Arabia,” IUCN/NCWCD Specialist Report, Riyadh, 1989.

[54] MSC, "Seawater Density and Salinity: Lesson Plan, UCLA,” 2011.

http://www.msc.ucla.edu/oceanblobe/pdf/densitysalinity/ densityintro.pdf

[55] S. A. Morcos, "Physical and Chemical Oceanography of the Red Sea," Oceanography and Marine Biology: An Annual Review, Vol. 8, 1970, pp. 73-202.

[56] F. Nansen, "Indian Ocean Fishery and Development Pro- 
gramme: Pelagic Fish Assessment Survey North Arabian Sea; Hydrographic Survey Results,” 1975.

http://www.fao.org/WAIRDOCS/FNS/FN023E/ch2.htm.

[57] F. J. Edwards, "Climate and Oceanography, Key Environments: Red Sea,” Pergamon Press, Oxford, 1987.

[58] P. G. Brewer and D. Dryssen, "Chemical Oceanography of the Persian Gulf,” Progress in Oceanography, Vol. 14, No. 1-4, 1985, pp. 41-55. doi:10.1016/0079-6611(85)90004-7

[59] M. Shahin, "Review and Assessment of Water Resources in the Arab region," Water International, Vol. 14, No. 4, 1989, pp. 206-209. doi:10.1080/02508068908692109

[60] V. C. John, S. L. Coles and A. I. Abozed, "Seasonal Cycle of Temperature, Salinity and Water Masses of the Western Arabian Gulf,” Oceanography Acta, Vol. 13, 1990, pp. 273-281.

[61] H. Swenson, "Why the Ocean is Salty. USGS publication," 2011.

http://www.palomar.edu/oceanography/salty_ocean.htm

[62] J. M. Hunt, E. E. Hays, E. T., Degens, et al., "Red Sea Detailed Survey of Hot Brine Areas, Science," Science, Vol. 156, No. 3774, 1967, pp. 514-516. doi:10.1126/science.156.3774.514

[63] F. T., Degens and D. A. Ross, "Hot Brines and Recent Heavy Metal Deposits in the Red Sea: A Geochemical and Geophysical Account," Springer-Verlag, Berlin, Heidelberg and New York, 1969.

[64] A. R. Miller, C. D. Densmore, E. T. Degens, et al., "Hot Brines and Recent Iron Deposits in Deeps of the Red Sea," Geochimica et Cosmochimica Acta, Vol. 30, No. 3, 1966. doi:10.1016/0016-7037(66)90007-X

[65] G. Blanc and P. Anschutz, "New Stratification in the Hydrothermal Brine System of the Atlantis II Deep, Red Sea," Geology, Vol. 23, No. 6, 1995, pp. 543-546. doi:10.1130/0091-7613(1995)023<0543:NSITHB >2.3.C O;2

[66] M. Hartmann, J. C. Scholten, P. Stoffers, et al., "Hydrographic Structure of Brine-Filled Deeps in the Red Sea: New Results from the Shaban, Kebrit, Atlantis II and Discovery Deep,” Marine Geology, Vol. 144, No. 4, 1998, pp. 311-330. doi:10.1016/S0025-3227(97)00055-8

[67] Y. Thisse, P. Guennoc, G. Pouit, et al., "The Red Sea: A Natural Geodynamic and Metallogenic Laboratory,” Episodes 3, 1983, pp. 3-9.

[68] F. T. Manheim, "Red Sea Geochemistry: Integrated Ocean Drilling Program Report. Woods Hole Oceanographic Institution," Deep Sea Drilling Project, Washington DC, 2007, pp. 975-998,

[69] M. Hovland, H. Rueslåtten, T. Kutznetsova, et al., "Numerical Modeling of Supercritical 'Out-Salting' in the “Atlantis II Deep” (Red Sea) Hydrothermal System,” The Open Geology Journal, Vol. 1, No. 1, 2007, pp. 1-6.

[70] G. Winckler, R. Kipfer, W. Aeschbach-Hertig, et al., "Sub Sea Floor Boiling of Red Sea Brines: New Indication from Noble Gas Data," Geochimica et Cosmochimica Acta, Vol. 64, No. 9, 2000, pp.1567-1575. doi:10.1016/S0016-7037(99)00441-X
[71] D. Smeed, “Chocking of Red Sea,” 2006. http://www.noc.ston.ac.uk/JRD/PROC/people/das/redsea php

[72] M. A. Al-Sahlawi, "Seawater Desalination in Saudi Arabia: Economic Review and Demand Projections," Desalination, Vol. 123, No. 2-3, 1999. doi:10.1016/S0011-9164(99)00067-3

[73] UNEP, “Threats, Red Sea and Gulf of Aden: Regional Seas," 2002. http://www.unep.ch/regional_seas/persga/redthreats.html

[74] UNEP, "Private Sectors and NGOs Actors Initiatives: International Petroleum Industry Environmental Conservation Association (IPIECA),” 2002. http://www.oils.gpa.unep.org/framework/region-12.htm

[75] Y. Nasser, "Coral Reefs at Risk-Trade \& Tourism in Red Sea and Its Threat to the Environment,” 2003. http://www1.american.edu/TED/ted.htm

[76] Y. Nasser, “Terrorism in Red Sea,” 2003. http://www1.american.edu/TED/redsea.htm

[77] A. U. Malik, F. Al-Muaili and M. Al-Hajri, "Failure of SWCC Water Transmission Pipelines and Follow-Up Rehabilita- tion Work-A review,” 2008. http://ipac.kacst.edu.sa/eDec/2008/172034_1.pdf

[78] S. Latteman and T. Hoper, "Environmental Impact and Impact Assessment of Seawater Desalination,” Desalination, Vol. 220, No.1-3. 2008, pp. 1-15. doi:10.1016/j.desal.2007.03.009

[79] F. Nadim, A. C. Bagtzoglou and J. Iranmahboob, "Coastal management in the Persian Gulf Region within the Framework of the ROPME Programme of Action," Ocean and Coast Management, Vol. 51, No. 7, 2008, pp. 556-565. doi:10.1016/j.ocecoaman.2008.04.007

[80] M. E. Barry, F. M. Houdre, A. B. Mclister, et al., "Three Dimensional Hydraulic and Water Quality Modeling of the Red Sea: Challenges \& Learnings," Proceedings of 18th World MACS/MODSIM congress, Cairns, 2009.

[81] N. Hagens, "The Oil Drum, What Is Our Oil Doing in Their Economic?-Saudi Oil Consumption Trends,” 2011. http://www.theoildrum.com/node/7767

[82] L. D. Talley, G. L. Pickard, W. J. Emery, et al., "Gravity Waves, Tides, and Coastal Oceanography: Descriptive Physical Oceanography," 6th Edition, Elsevier, Amsterdam, 2011.

[83] ITOPF, "Red Sea \& Gulf of Aden: The Risk of Oil Spills. The International Tanker Owners Pollution Foundation Limited,” 2003. www.itopf.com/regional_profiles

[84] Wikipedia, “The Jebel al-Zayt oil spill,” 2011. http://en.wikipedia.org/wiki/JJebel_al-Zayt_oil_spill

[85] J. D. Lowell and G. J. Genik, Sea-Floor Spreading and Structural Evolution of Southern Red Sea. AAPG Bulletin, Vol. 56, No. 2, 1972, pp. 247-259.

[86] R. B. Whitmarsh, O. E. Weser and D. A. Ross, "Initial Reports of the Deep Sea Drilling Project," US Government Printing Office, Washington DC, 1974. doi:10.2973/dsdp.proc.23.1974 